\title{
HUBUNGAN KARAKTERISTIK INDIVIDU DENGAN TINGKAT PENGETAHUAN MASYARAKAT TENTANG PENYAKIT HIV/AIDS DI BEKASI
}

\author{
Yana Aprianingsih ${ }^{1}$, Sondang Ratnauli Sianturi ${ }^{2}$ \\ ${ }^{1-2}$ Sekolah Tinggi Ilmu Kesehatan Sint Carolus \\ Email: sondangrsianturi@gmail.com
}

\begin{abstract}
ABSTRAK
HIV/AIDS merupakan isu global dengan prevalensi besar. Pengetahuan akan HIV/AIDS perlu dimiliki oleh masyarakat sehingga pencegahan dan penularan HIV/AIDS dapat ditangani dengan baik. Tujuan penelitian ini adalah untuk diketahuinya hubungan karakteristik individu meliputi usia, jenis kelamin, pendidikan, pekerjaan, sumber informasi dengan pengetahuan masyarakat tentang penyakit HIV/AIDS di RW 07 Desa Setia Asih. Penelitian ini menggunakan desain deskriptif korelatif dengan pendekatan cross sectional. Populasi penelitian adalah masyarakat RW 07 yang sudah menikah dan berumur 24 tahun. Pengambilan sampel menggunakan teknik total sampling yang didasarkan pada kriteria yang telah ditetapkan oleh peneliti, dengan jumlah responden sebanyak 160 warga. Analisis statistik menggunakan uji Chi-Square, Kendall's Tau B dan C. Hasil penelitian menunjukkan sebanyak $(36,3 \%)$ responden usia yang berusia 26-35 tahun memiliki pengetahuan baik, pada jenis kelamin perempuan $(36,9 \%)$ memiliki pengetahuan baik, pada pendidikan SMA $(21,3 \%)$ memiliki pengetahuan baik, sedangkan pada pekerjaan karyawan $(20,6 \%)$ memiliki pengetahuan baik. Simpulan dari peneliti adalah tidak ada hubungan bemakna antara usia, jenis kelamin, pekerjaan,sumber informasi dengan pengetahuan, adanya hubungan antara pendidikan dengan pengetahuan dengan nilai $p=$ value 0,034 ( $\mathrm{p}<0,05$ ). Pendidikan yang cukup dapat meningkatkan pengetahuan masyarakat, sehingga dapat berdampak pada perilaku yang sehat.
\end{abstract}

Kata Kunci: HIV/AIDS, Karakteristik individu, Pengetahuan

\begin{abstract}
HIV/AIDS is a global issue with a large prevalence. Knowledge of HIV/AIDS needs to be owned by the community so that prevention and transmission of HIV/AIDS can be handled properly. The purpose of this study was to determine the relationship of individual characteristics including age, sex, education, occupation, source of information with the level of knowledge of people about HIV/AIDS in the RW 07 Desa Setia Asih. This research uses quantitative methods with descriptive correlative and cross sectional approach. The study was conducted measuring tools and sampling method with a total sampling of respondents were 160 people the village of Desa setia asih $R W$ 07. Statisstical analysis using Chi-square test and Kendall Tau B and C. The results of the research showed (36,3\%) of respondents aged 26-35 years had good knowledge, in female sex (36,9\%) had good knowledge, in hight school education (21,3\%) had good knowledge, while for employee job (20,6\%) had good knowledge. The conlusion of the researchers was that there was no significant relationship between age, occupation, source of information and knowledge, the relationship between education and
\end{abstract}


knowledge with a value of $p=$ value 0,034 ( $p<0,05)$.Adequate education can increase people's knowledge, so that it can have an impact on healthy behavior.

\section{Keywords: Characteristic individu, Knowledge, HIV/AIDS}

\section{LATAR BELAKANG}

Penyakit HIV/AIDS adalah salah satu penyakit yang memastikan di dunia. WHO menyatakan AIDS merupakan permasalahan global. Berdasarkan usia, kasus HIV/AIDS di Indonesia banyak diderita oleh usia produktif 25 - 49 tahun, dan usia remaja 15- 19 tahun (Infodatin,2014). Indonesia merupakan negara peringkat ketiga yang memiliki jumlah kasus HIV didunia, bahkan terdapat peningkatan jumlah kasus baru setiap tahunnya (Culbert,2014). Laporan data perkembangan HIV/AIDS menurut KEMENKES RI pada bulan Januari - Maret 2017 yaitu jumlah infeksi HIV/AIDS dilaporkan sebanyak 11.409 orang, dengan presentase kelompok umur 25-49 tahun sebanyak 69,6\%, dan kelompok umur 20-24 tahun (17,6\%). Rasio HIV/AIDS antara perempuan dan laki-laki adalah 1:2, provinsi 5 teratas yang melaporkan jumlah kasus HIV terbanyak pada bulan Januari - Maret 2017 yaitu : Jawa Timur 1.614 orang, Jawa Barat 1.505 orang, DKI Jakarta 1403 orang, Jawa Tengah 1.711 orang, dan Papua 861 orang.

Provinsi Jawa barat merupakan urutan ke dua tertinggi pada kasus HIV/AIDS, didalamnya termasuk RSUD Kota Bekasi yang menjadi pusat rujukan rumah sakit di wilayah daerah Bekasi. Kepala Dinas Kesehatan Kota Bekasi Kusnanto Saidi mengatakan jumlah pengidap kasus HIV/AIDS di RSUD Kota bekasi sampai Oktober 2016 yaitu jumlah penderita HIV mencapai 3.434 orang, dan kasus AIDS mencapai 1.206 orang dengan faktor resiko diantaranya adalah homosexsual sebanyak 5\%, heteroseksual 42,9\%, bisexsual 5\%, perinatal $4 \%$, napza suntik 44,5\%, tatto 0,1\% dll (Pantja warta kota bekasi,2016).

Kemenkes(2012) melaporkan kejadian HIV/AIDS lebih banyak terjadi pada kelompok usia dewasa, Sampai akhir tahun 2012 tercatat 73,7 \% kasus HIV terjadi pada umur 25-49 tahun, $15 \%$ pada umur 20-24 tahun dan 4,5\% terjadi pada umur > 50 tahun. Banyak masyarakat yang tidak mengenal penyakit HIV/AIDS karena kurangnya pengetahuan tentang HIV/AIDS, dan kurangnya pengetahuan masyarakat cara penularan HIV/AIDS, cara pencegahan agar tidak tertular penyakit HIV/AIDS.

Penularan AIDS di Indonesia saat ini lebih dominan terhadap perilaku seksual, dahulu penularan HIV/AIDS di Indonesia lebih banyak disebabkan karena penggunaan obat-obatan terlarang dan narkotika (Anonim, 2012). Menurut Butt (2010) menyatakan bahwa banyaknya informasi tidak benar yang diterima oleh masyarakat di wilayah Pegunungan Papua terkait penularan mengenai HIV/AIDS. Kepala Dinas Kesehatan RSUD kota Bekasi mengupayakan dukungan meliputi sejumlah program prioritas di antaranya peningkatan akses layanan HIV/AIDS, seperti tes HIV dan pengobatannya, serta penyediaan layanan HIV/AIDS yang berkualitas dan terjangkau oleh masyarakat. Peningkatan jumlah penderita HIV/AIDS dari tahun ke tahun dilaporkan dikota bekasi diakibatkan karena masih rendahnya pengetahuan masyarakat terkait penyakit HIV/AIDS. (Warta kota bekasi). Hasil penelitian Ida Barooh (2014) menunjukan bahwa pengetahuan masyarakat tentang HIV/AIDS, PMS, dan gambaran penyakit HIV dan AIDS masih sangat terbatas. Terbatasnya pengetahuan masyarakat salah satunya disebabkan oleh kurangnya sosialisasi.

Faktor- faktor yang mempengaruhi pengetahuan yaitu pendidikan, pekerjaan, umur, faktor lingkungan dan sosial budaya (Wawan 2010). Penelitian Sudikno(2010) menunjukkan bahwa persentase pengetahuan HIV dan AIDS pada remaja dengan kategori kurang masih cukup besar $(48,9 \%)$, persentase remaja yang mampu menjawab dengan benar pengetahuan HIV dan AIDS hanya sebesar 0,3\%. Penelitian yang dilakukan Oktarina (2012) menyebutkan 
bahwa sebagian besar responden memperlihatkan sikap penolakan terhadap ODHA yang dipengaruhi oleh banyak faktor, salah satunya adalah tentang pengetahuan tentang HIV/AIDS. Pengetahuan penduduk Indonesia mengenai HIV/AIDS tergolong masih rendah, laporan SDKI,(2012) menunjukan bahwa tingkat pengetahuan tentang HIV/AIDS masih rendah terlihat dari data yang menunjukan bahwa presentase wanita umur 15- 49 tahun yang mendengar tentang HIV/AIDS hanya sebesar 76,7\%, sedangkan laki -laki yang berumur 1549 tahun yang pernah mendengar tentang HIV/AIDS sebesar 82,3\%.

Tingkat pengetahuan seseorang dapat mempengaruhi seseorang untuk melakukan tindakan (Jaelani,2017) hal ini memberikan landaan kognitif untuk terbentuknya perilaku (MC Manus, 2008), sehingga makin tinggi tingkat pengetahuan seseorang maka akan semakin kecil kemungkinan untuk melakukan perilaku seksual pranikah. Indonesia telah melakukan program indicator kegiatan mencakup pelaksanaan program nasional, yaitu perluasaan dan peningkatan pencegahan kombinasi kasus HIV/AIDS, perluasan dan peningkatan mutu pelayanan, perawatan, dukungan dan pengobatan, pengurangan infeksi HIV vertical, perluasan cakupan mitigasi dampak, penciptaan lingkungan yang mendukung serta peningkatan keberlanjutan dan peningkatan manajemen pengetahuan upaya penanggulan AIDS untuk meningkatan pengetahuan masyarakat tentang penyakit HIV/AIDS.

Strategi nasional penanggulan AIDS di Indonesia, ada dua pendekatan kesehatan masyarakat dan pendekatan social\& keagamaan. Program pengendalian HIV/AIDS (2016) mengatakan faktanya program nasional yang sudah dilakukan pencapaian belum maksimal, masyarakat masih banyak belum mengetahui penyakit HIV/AIDS karena masih rendahnya tingkat pendidikan, lurangnya untuk mencari sumber informasi terkait dengan kesehatan, lingkungan yang tidak mendukung, kurangnya sosialisasi mengenai penyakit HIV/AIDS, perilaku seks yang berulang-ulang, dan kurangnya promosi kesehatan khususnya promosi penggunaan kondom secara terbuka dengan kurang mendapat persetujuan dari kelompok agamawan sehingga terjadi kontroversial dan menghambat upaya pengembangan program pencegahan HIV/AIDS.

Hasil wawancara pada 2 orang warga Kepala RW 07 dan Ketua RT 01 dengan rentang usia 25 - 40 tahun dan pendidikan rendah, rata - rata belum pernah mendapatkan penyuluhan mengenai penyakit HIV/AIDS, sehingga masyarakat tidak mengetahui terkait pola hidup sehat untuk mencegah penyakit HIV/AIDS. Hal ini dapat dilihat dari kejadian salah satu warga RW 07 yang pernah terkena penyakit HIV/AIDS akibat gonta - ganti pasangan.

\section{METODE PENELITIAN}

Penelitian ini menggunakan metode kuantitatif dengan desain penelitian deskriptif korelatif dan pendekatan cross sectional. Penelitian dengan metode deskriptif bertujuan untuk mengamati ,menjelaskan, mendeskripsikan gambaran terhadap obyek yang di teliti dan untuk generasi hipotesis atau pengembangan teori (Polit\&Beck, 2012). Penelitian ini menggunakan pendekatan cross sectional karena pengukuran variabel independen dan varaibel dependen dilakukan sekali dalam waktu yang sama. Populasi adalah keseluruhan jumlah anggota dari suatu himpunan yang ingin diketahui karakteristiknya berdasarkan inferensi atau generelasasinya (Supardi, 2013). Populasi penelitian berjumlah 250 orang, yaitu masyarakat RW 07, Desa Setia Asih. Pengambilan sampel yang di gunakan dalam penelitian ini adalah non probablity sampling dengan teknik total sampling.

Pengumpulan data dilakukan oleh peneliti menggunakan kuesioner sebagai sarana untuk mendapatkan informasi dari responden. Kuesioner yang di buat oleh peneliti mengacu pada kerangka konsep yang meliputi: kuesioner data karakteristik responden, kuesioner pengukuran pengetahuan responden tentang penyakit HIV/AIDS. Semua pertanyaan dari kuesioner dilakukan uji validitas dan reliabilitas yaitu pertanyaan yang valid (32 pertanyaan) dengan nilai $r$ hitung $>$ dari $r$ hitung dengan nilai $r$ 0,991 dan nilai alpha >0,991 (reliabel), 
sehingga instrumen dapat dijadikan instrumen penelitian. Analisa bivariat yang digunakan dalam penelitian ini berupa uji Chi square, uji Kendalls tau c.

\section{HASIL DAN PEMBAHASAN}

\section{Analisis Univariat}

Analisa univariat dalam penelitian ini disajikan berupa distribusi frekuensi dari setiap variabel independen yaitu karakteristik individu (Usia, jenis kelamin, pendidikan terakhir, pekerjaan dan sumber informasi) dengan variabel dependen pengetahuan masyarakat tentang penyakit HIV/AIDS di RW 07 Desa Setia Asih.

Tabel 1. Karakteristik Individu Responden

\begin{tabular}{llcc}
\hline \multicolumn{1}{l}{ Karakteristik Individu } & $\mathbf{n}$ & \% \\
\hline Usia & $26-35$ tahun (Dewasa Awal) & 117 & 73,1 \\
& $36-45$ tahun (Dewasa Akhir) & 40 & 25 \\
& 46-55 tahun (Lansia Awal) & 3 & 1,9 \\
\hline Jenis Kelamin & Perempuan & 119 & 74,4 \\
& Laki-laki & 41 & 25,6 \\
\hline Pendidikan & SD & 4 & 2,5 \\
Terakhir & SMP & 24 & 15 \\
& SMA & 64 & 40 \\
& D3 & 28 & 17,5 \\
& S1 & 40 & 25 \\
\hline Pekerjaan & IRT & 60 & 37,5 \\
& Karyawan & 53 & 33,1 \\
& Wiraswasta & 28 & 17,5 \\
& PNS & 19 & 11,9 \\
\hline Terpapar & Terpapar & 158 & 98,8 \\
Informasi & Tidak Terpapar & 2 & 1,2 \\
\hline Pengetahuan & Baik & 85 & 53,1 \\
& Kurang & 75 & 46,9 \\
\hline
\end{tabular}

Hasil analisis tabel 1, pada usia ini kemampuan berpikir kritis pada setiap individu mulai meningkat secara teratur selama usia dewasa awal dan pertengahan, pada usia ini juga seseorang akan mulai belajar memecahkan masalah (Perry Potter, 2009). Sebagian besar responden berjenis kelamin perempuan sebanyak 119 responden $(74,4 \%)$. Hal ini terjadi karena warga di RW 07 lebih dominan yang datang mengisi kuesioner adalah perempuan.

Sebagian besar responden memiliki pendidikan terakhir SMA (Sekolah Menengah Atas) sebanyak 64 responden (40\%), dan 40 responden (25\%) memiliki pendidikan perguruan tinggi. Pendidikan merupakan usaha sadar dan terencana untuk mengembangkan potensi dirinya untuk memiliki kekuatan spiritual keagamaan, pengendalian diri, kepribadian, kecerdasan serta keterampilan yang diperlukan untuk dirinya, masyarakat, bangsa dan Negara. (Notoadmodjo,2012).

Sebagian besar responden tidak memiliki pekerjaan sebanyak 60 responden $(37.5 \%)$ adalah Ibu rumah tangga (IRT). Hal ini terjadi karena dari hasil wawancara beberapa warga RW07 tidak memiliki pekerjaan hanya sebagai ibu rumah tangga (IRT) mengaku karna tidak ada pendidikannya dan bingung mencari pekerjaan.

Sebagian besar responden terpapar informasi dengan informasi penyakit HIV/AIDS paling besar 158 responden $(98.8 \%)$. Hal itu dikarenakan, hampir semua responden memiliki smartphone dan menonton atau melihat dari berbagai media elektronik tentang penyakit HIV/AIDS. Data yang didapat saat penelitian dari beberapa sumber informasi yang paling banyak responden dapatkan yaitu dari sumber informasi media elektronik Internet/Radio/TV sebanyak $84.7 \%$. Sebagian besar responden memiliki pengetahuan baik tentang HIV/AIDS 85 responden $(53,1 \%)$. Hal itu dikarenakan sebagian besar warga yang sudah memiliki 
pendidikan minimal SMA sudah pernah mendapat penyuluhan di puskesmas tentang penyakit HIV/AIDS.

\section{Analisis Bivariat}

Analisis bivariat dilakukan untuk melihat hubungan antara variabel, yaitu variabel independen (karakteristik individu) dengan variabel dependen yaitu pengetahuan tentang penyakit HIV/AIDS.

Tabel 2 Hubungan Karakteristik dengan Pengetahuan Masyarakat tentang penyakit HIV/AIDS

\begin{tabular}{|c|c|c|c|c|c|c|c|}
\hline \multirow{2}{*}{\multicolumn{2}{|c|}{ Variabel }} & \multicolumn{2}{|c|}{ Pengetahuan Buruk } & \multicolumn{2}{|c|}{ Pengetahuan Baik } & \multirow{2}{*}{ Total } & \multirow{2}{*}{$\begin{array}{l}P \\
\text { value }\end{array}$} \\
\hline & & n & $\%$ & $\mathbf{n}$ & $\%$ & & \\
\hline Usia & $\begin{array}{l}\text { 26-35 tahun (Dewasa } \\
\text { Awal) } \\
\text { 36-45 tahun (Dewasa } \\
\text { Akhir) } \\
46-55 \text { tahun (Lansia } \\
\text { Awal) }\end{array}$ & $\begin{array}{c}59 \\
15 \\
1\end{array}$ & $\begin{array}{c}36,9 \\
9,4 \\
0,6\end{array}$ & $\begin{array}{c}58 \\
25 \\
2\end{array}$ & $\begin{array}{c}36,3 \\
15,6 \\
1,3\end{array}$ & $\begin{array}{c}117 \\
40 \\
3\end{array}$ & 0,130 \\
\hline $\begin{array}{l}\text { Jenis } \\
\text { Kelamin }\end{array}$ & $\begin{array}{l}\text { Perempuan } \\
\text { Laki-laki }\end{array}$ & $\begin{array}{l}59 \\
26 \\
\end{array}$ & $\begin{array}{l}36,9 \\
16,3 \\
\end{array}$ & $\begin{array}{l}60 \\
15 \\
\end{array}$ & $\begin{array}{c}37,5 \\
9,4 \\
\end{array}$ & $\begin{array}{c}119 \\
41 \\
\end{array}$ & 0,127 \\
\hline $\begin{array}{l}\text { Pendidikan } \\
\text { Terakhir }\end{array}$ & $\begin{array}{l}\text { SD } \\
\text { SMP } \\
\text { SMA } \\
\text { D3 } \\
\text { S1 } \\
\end{array}$ & $\begin{array}{c}1 \\
14 \\
30 \\
15 \\
15 \\
\end{array}$ & $\begin{array}{c}0,6 \\
8,8 \\
18,8 \\
9,4 \\
9,4 \\
\end{array}$ & $\begin{array}{c}3 \\
10 \\
34 \\
13 \\
25\end{array}$ & $\begin{array}{c}1,9 \\
6,3 \\
21,3 \\
8,1 \\
15,4 \\
\end{array}$ & $\begin{array}{c}4 \\
24 \\
64 \\
28 \\
40 \\
\end{array}$ & 0,034 \\
\hline Pekerjaan & $\begin{array}{l}\text { IRT } \\
\text { Karyawan } \\
\text { Wiraswasta } \\
\text { PNS }\end{array}$ & $\begin{array}{c}28 \\
33 \\
15 \\
9 \\
\end{array}$ & $\begin{array}{c}17,5 \\
20,6 \\
9,4 \\
5,6\end{array}$ & $\begin{array}{l}32 \\
20 \\
13 \\
10\end{array}$ & $\begin{array}{c}20 \\
12,5 \\
8,1 \\
6,3 \\
\end{array}$ & $\begin{array}{l}60 \\
53 \\
28 \\
19 \\
\end{array}$ & 0,078 \\
\hline $\begin{array}{l}\text { Terpapar } \\
\text { Informasi }\end{array}$ & $\begin{array}{l}\text { Terpapar } \\
\text { Tidak Terpapar }\end{array}$ & $\begin{array}{c}85 \\
0\end{array}$ & $\begin{array}{c}53,1 \\
0,0\end{array}$ & $\begin{array}{c}73 \\
2\end{array}$ & $\begin{array}{c}45,6 \\
1,3\end{array}$ & $\begin{array}{c}158 \\
2\end{array}$ & 0,152 \\
\hline
\end{tabular}

Tabel 2 menunjukkan bahwa berdasarkan uji statistik menggunakan Uji Kendall's tau $\mathrm{C}$ didapatkan $p$-value sebesar 0,130 dengan $\alpha=0.05$ artinya tidak ada hubungan bermakna antara usia dengan pengetahuan di RW 07 Desa Setia Asih. Hasil Penelitian ini sejalan dengan penelitian Romadaniah (2013) yang menyatakan bahwa tidak ada hubungan antara usia dengan pengetahuan HIV/AIDS dengan hasil p-value sebesar $0,164(>0,05)$. Hal ini disebabkan karena pengetahuan HIV/AIDS tidak dipengaruhi oleh usia saja, melainkan dapat dipengaruhi oleh beberapa faktor lain, seperti sikap orang dalam menerima pengetahuan mengenai HIV/AIDS.

Ditinjau dari jenis kelamin, penelitian ini menunjukkan bahwa sebagian besar responden berjenis kelamin perempuan memiliki pengetahuan baik $(37,5 \%)$. Hasil uji chisquare antara variabel jenis kelamin dengan pengetahuan HIV/AIDS didapatkan nilai $p$ value 0.127 ( $>0.05$ ) yang artinya tidak ada hubungan bermakna antara jenis kelamin dengan pengetahuan tentang penyakit HIV/AIDS. Tesiman $\operatorname{dkk}(2016)$ " Prevelansi dan faktor predictor atopi pada pasien HIV/AIDS" mengatakan bahwa tidak terdapat hubungan antara jenis kelamin dengan kejadian atopi pada pasien HIV/AIDS dengan $p=v a l u e ~ 0,807(>0,05)$.

Pada tabel 2 menunjukkan hasil uji kendall's tau B didapatkan nilai $p$ value 0.034 (p $<0.05)$ yang berarti ada hubungan bermakna antara pendidikan dengan pengetahuan masyarakat tentang penyakit HIV/AIDS. Hasil Penelitian yang berkaitan dengan pekerjaan responden ini tidak ada hubungan dengan pengetahuan responden dengan nilai $p$ value 0.078 ( $>0.05$ ). Hal ini bisa terjadi karena jenis pekerjaan pada responden bervariasi. Pekerjaan responden sebagian besar adalah tidak bekerja yaitu IRT, responden sebagian besar sibuk 
dengan pekerjaanya sehingga responden tidak ada rasa ingin tahu dalam mencari informasi tentang penyakit HIV/AIDS.

Berdasarkan variable responden yang terpapar informasi tentang penyakit HIV/AIDS dan memiliki pengetahuan yang baik sebanyak 158 responden $(98,8 \%)$. Hasil analisis kendall's tau B didapatkan nilai $p$ value 0.152 ( $p>0.05)$ yang artinya tidak ada hubungan bermakna antara keterpaparan informasi dengan pengetahuan masyarakat tentang penyakit HIV/AIDS di RW 07 Desa Setia Setia Asih. Teknologi informasi yang semakin canggih dan berkembang memudahkan remaja untuk mengakses informasi setiap saat seperti media cetak (koran, majalah, buku) dan media elektronik (TV, VCD radio, internet). Hasil ini sejalan dengan penelitian Lisnawati dan Lestari (2015) di SMKN 1 Cirebon yang menunjukkan tidak terdapat hubungan antara sumber informasi dengan pengetahuan tent ang penyakit HIV/AIDS, dimana hasil uji statistik didapat nilai $p=$ value 0.093 ( $\mathrm{p}>0.05)$. Peneliti bersumsi tidak ada hubungan bermakna antara sumber informasi dengan pengetahuan, hal ini terjadi karena responden kurang menerima sumber informasi mengenai penyakit HIV/AIDS, masyarakat juga belum mengenal penyakit HIV/AIDS, terkait dengan cara penularan, tanda-gejala, cara pencegahannya sehingga responden hanya mencari sumber informasi di media sosial jika responden sedang sakit, lebih banyak responden pada zaman sekarang tidak menggunakan berbagai sumber informasi dengan baik sehingga kurangnya informasi yang dimiliki masyarakat terkait berbagai penyakitnya

\section{SIMPULAN DAN SARAN \\ Simpulan}

Hasil penelitian menunjukkan bahwa tingkat pengetahuan masyarakat tentang penyakit HIV/AIDS di RW 07 Desa Setia Asih masih belum diketahui secara optimal dengan responden pada usia masa dewasa awal 26- 35 tahun $(73,1 \%)$ dan sebagian besar berjenis kelamin perempuan serta memiliki tingkat pendidikan yang cukup dan tingginya paparan informasi yang didapatkan. Hasil penelitian menunjukkan bahwa tidak adanya hubungan antara usia, jenis kelamin, pekerjaan dan terpaparnya informasi terhadap tingkat pengetahuan seseorang tentang HIV/AIDS, tetapi pendidikan memiliki hubungan yang significant terhadap tingkat pengetahuan.

Berdasarkan hasil penelitian ini maka diharapkan kepada petugas kesehatan untuk turun ke lapangan dan meningkatkan pengetahuan masyarakat dalam bentuk penyuluhan tentang penyakit HIV/AIDS agar masyarakat mengenal cara pencegahan \& cara penularan penyakit.

\section{DAFTAR PUSTAKA}

Andi (2013) - Gambaran pengetahuan ibu tentang HIV/AIDS di UPTD puskesmas pondok kelapa kota bekasi.

Anonim. 2012, Mei 22. Terjadi Pergeseran Pola Penularan HIV/AIDS di Indonesia.

Badan Pusat Statistika.(2017) . Survei Demografi dan Kesehatan Indonesia. Jakarta:

Kementerian Kesehatan.

Bunga \& Tarigan. (2011). Panduan Riset Keperawatan Program S1 Keperawatan. Jakarta: Stik Sint Carolus Jakarta.

Culber, (2014) G.J, Levy, J Norr Journal Of The Association of Nurses in AIDS Car Dinkes Jabar. (2012). Profil Kesehatan Propinsi Jawa Barat.Bandung.

Feilicia Henrica Teja, R. R. (2013). Chlamydial Infection Prevalence In Human Immunodeficiency Virus Patient. International Journal of Integrated Health Sciences, 428 .

Global health estimates 2015: deaths by cause, age, sex, by country and by region, 2000 2015. Geneva: World Health Organization; 2016. 
HIV/AIDS dan IMS :Penularan dan Pencegahan-(Buku Saku) Http://poskotanews.com/2018/03/31/pengidap-hiv-aids-kotabekasi-bekasi-bertambahDiakses, Sabtu,31 Maret 2018 -15:31 WIB.

http:// www.pdpersi.co.id/content/news.php? catid=23\&mid=5\&nid Diakses tanggal 26 Juni 2012, pukul 19:00 WIB.

http://wartakota.tribunnews.com/2016/12/01/kasus-hiv-aids-kota-bekasi-meningkat Diakses, Sabtu,31 Maret 2018 15:45

https://biz kompas.com/read/2017/08/09/203900828/kasus-hiv-aids-di-jawa-barat-terusbertambah. Diakses, Sabtu 31 Maret 2018 - 16:00 WIB

http://poskotanews.com/2018/03/31/pengidap-hivaids-di-kabupaten-bekasi-bertambah-40. Diakses, Senin, 2 April 2018 - 13:06 WIB.

http://siha.depkes.go.id/portal/files_upload/4_Pedoman_Fasyankes_Primer_ok.pdf Senin, 2 April 2018 - 13:06 WIB.

Immunodeficiency Virus Patient. International Journal of Integrated Health Sciences, 428. Infodatin, (2014). Situasi dan Analisis HIV AIDS Pusat Data dan Informasi Kesehatan RI. KBBI. (2016). Kamus Besar Bahasa Indonesia. Jakarta: Publiser Cempaka Indah.

Kepmenkes, (2016). Informasi Pusat Data dan Informasi Kementrian Kesehatan RI.

Kejadian Dengan Kejadian HIV (+) Pada Kalangan Pengguna Narkotika Suntik di Indonesia Tahun 2011 (Analisis Data STBP Tahun 2011 (Thesis). Depok: FKM UI.

Lily Syarif Nurhalina (2012) Tingkat pengetahuan mengenai HIV/AIDS kurang mempunyai resiko tertular.

Najmuddin, Djamilah. 2012, Mei 24. Infeksi Oportunistik ODHA.

Noviana, N., (2016) Konsep HIV/AIDS Seksualitas dan Kesehatan Reproduksi. Jakarta :

CV.Trans Info Media.

Notoatmodjo, S. (2012). Metodologi Penelitian Kesehatan. Jakarta: Rineka Cipta.

Notoatmodjo, S. (2014). Ilmu Perilaku Kesehatan. Jakarta: Rineka Cipta.

Nursalam, (2015) Metodologi Penelitian Ilmu Keperawatan Pendekatan Praktis edisi 4 jakarta: Sumber Medika.

Nurhalina. (2012). Faktor Faktor Yang Berhubungan dengan karakteristik individu dengan pengetahuan HIV/AIDS di UPTD malang.

Oktarina, dkk (2012) Hubungan Karakteristik responden keadaan wilayah terhadap HIV/AIDS pada masyarakat Indonesia Buletin penelitian sistim Kesehatan Vol 12

Polit, D. F., \& Beck, T. C. (2012). Essentials of Nursing Research : Appraising evidence for Nursing Practice. China: Wolters Kluwer Health.

Rini. (2017). Gambaran pengetahuan masyarakat tentang penularan HIV/AIDS pada pasien yang melakukan pencabutan gigi dan mulut unsyiah.

Susilo, Wilhelmus Hary ; Aima, Havidz ; Suprapti, Fitriana (2014) Biostatistika lanjut dan aplikasi riset. Jakarta : TIM.

Sugiyono. (2013). Metode Penelitian Kombinasi (Mixed Methods). Bandung: CV.Alfabeta.

Wawan, A., \&Dewi. (2011). Teori \&Pengukuran Pengetahuan Sikap dan Perilaku Manusia Jakarta: Mufia medika.

Wawan \& Dewi. (2010). Teori \& Pengukuran Pengetahuan, Sikap dan Perilaku Manusa di lengkapi Contoh. Yogyakarta: Nuha Medika. 